\title{
T-Cell Prolymphocytic Leukemia Accompanied by Plural M-Proteins with Myelodysplastic Syndrome in a Nonagenarian
}

\author{
Nagahito Saito $^{1 *}$, Katsuhiro Higashiura ${ }^{1}$, Kenta Honma ${ }^{1}$, Shinji Kurosawa ${ }^{1}$, Kazunori Ehata ${ }^{1}$, Tomoyuki Yanami ${ }^{1}$, Katsumi Katagiri', Hiroyuki \\ Sugiki ${ }^{2}$ and Hong Kean $\mathrm{Ooi}^{3,4 *}$
}

1 Internal Medicine, Nemuro City Hospital, Nemuro, Hokkaido, Japan

2Internal Medicine, Nemuro Kyoritsu Hospital, Nemuro, Hokkaido, Japan

${ }^{3}$ Veterinary Medicine, National Chung Hsing University, Taichung, Taiwan

${ }^{4}$ Veterinary Medicine, Yamaguchi University, Japan

\begin{abstract}
T-cell Pro-Lymphocytic Leukemia (T-PLL) is a rare disease caused by malignancy of mature post-thymic T-cell. Myelodysplastic Syndrome (MDS) is caused by abnormal differentiation of myeloid lineage cells resulting in myeloid leukemia. Both of these hematological disorders are frequently diagnosed in elderly persons. Myeloid lineage is believed to be situated at the position far from lymphoid one as it is regarded on a tree diagram about the blood cell maturation. We reported herein a rare case of T-PLL accompanied by plural M-proteins with MDS a nonagenarian. The 96 years old patient was admitted to our hospital because of lymphocytosis and abnormal lymphocytes. From the bone marrow aspirate, biopsy and hematological findings, abnormalities were observed in cells of three different lineages, namely, (i) neutrophils with hypersegmented-nuclei (ii) erythroblasts with nuclear division, large platelets and megakaryoblastic cells, and (iii) reticulum cells with phagocytosed iron in their cytoplasm. Lymphocytes showed CD3 (+), CD4 ( \pm$),$ CD5 (+), CD8 (+), CD10 (+), CD56 (-) and CD57 (-). Mast cells and large lymphocytic cells with nuclear pockets were also seen. Anti-HTLV-1 antibody was negative. Soluble IL-2 receptor was significantly elevated to $7910 \mathrm{U} / \mathrm{ml}$. Both IgG $\lambda$ and IgGKM-protein were detected. No Bence-Jones protein was detected in the urine. Chromosomal abnormality of $45(X, 0)$ or loss of $Y$ chromosome was also demonstrated. Due to his high age, it was difficult to classify his condition according to the conventional classification. Thus, what we had experienced is truly a rare case that coincidentally showed T-PLL and MDS with plural M-proteins.
\end{abstract}

Keywords: M-protein; Myelodysplastic syndrome; T-prolymphocytic leukemia

\section{Introduction}

T-cell prolymphocytic leukemia (T-PLL), which is commonly accompanied by splenomegaly, is a mature post-thymic T-cell malignancy with an aggressive clinical course. It is an extremely rare disorder accounting for the lowest number of all the lymphocytic leukemia [1]. This disease was previously known as T-cell chronic lymphocytic leukemia but has now been reclassified as T-PLL based on the post-thymic T-cell markers [2]. T-PLL is frequently diagnosed in elderly people [3].

Myelodysplastic syndrome (MDS) is a hematological disease caused by abnormal differentiation of myeloid lineage cells in which some patients will develop to several forms of myeloid leukemia [4]. MDS is also commonly seen in elderly persons [5]. Whatever the cause of both T-PLL and MDS, it is still a mystery that both of these hematological disorders are frequently diagnosed in elderly persons $[3,5]$.

Although there have been some reports showing concurrent lymphoid malignancies with MDS, almost all cases of these lymphoid malignancies associated with the MDS were of the B-cell type, which developed after therapy with drugs such as alkylating agents [6].

We present an oldest patient ever of T-PLL accompanied by plural M-proteins with MDS, without any previous chemotherapy.

\section{Case Report}

Patient Y.S, a 96-yr-old Japanese male, was referred from a practicing physician to our Nemuro city hospital because of a WBC count of $26.6 \times 10^{9} / \mathrm{L}$ with $75 \%$ lymphocytes. He was admitted to our hospital for a detailed examination of bone marrow aspiration and biopsy to make a definitive diagnosis of lymphocytic leukemia. $\mathrm{He}$ did not show any abnormal physical findings such as skin lesion nor lymphadenopathy on admission, except for splenomegaly.

His hematological data were as follows; Red Blood Cell count (RBC) $3.40 \times 10^{12} / \mathrm{L}$, Hemoglobin $(\mathrm{Hb}) 10.7 \mathrm{~g} / \mathrm{L}$, Hematocrit $(\mathrm{Ht}) 32.3 \%$, White Blood Cell count (WBC) $132 \times 10^{9} / \mathrm{L}$ with $87 \%$ lymphocytes and Platelet count $72 \times 10^{9} / \mathrm{L}$. By light microscopy, the lymphocytes in the peripheral blood smear were seen as small-sized lymphocyte with an irregular nuclear outline and condensed chromatin. Their cytoplasm was scant, non-granular and basophilic by May-GrünwaldGiemsa stain (Figure 1a). Free cells in aspirated bone marrow consisted of $82.8 \%$ lymphocyte and $0.2 \%$ plasma cell. In the biopsy specimens, the lymphocytes showed CD3 (+), CD4 ( \pm ), CD5 (+), CD8 (+), CD10 (+), CD56 (-) and CD57 (-) (Figure 2). Anti-HTLV-1 antibody was negative. Soluble IL-2 receptor was significantly elevated to $7910 \mathrm{U} / \mathrm{ml}$ (the normal range is $145 \sim 519$ ).

In addition to the presence of the abnormal lymphocytes, morphological abnormalities in three other cell lineages were also

*Corresponding authors: Nagahito Saito, Internal Medicine, Nemuro City Hospital, 1-2, Ariisocho, Nemuro, 087-8686, Japan, Tel: 81-153-24-3201; Fax: 81-15324-9693; E-mail: nagahito@hsp.city.nemuro.hokkaido.jp

Prof. Hong-Kean Ooi, Veterinary Medicine, National Chung Hsing University, 250 Kuo Kuang Road, Taichung, 40227, Taiwan, Tel: (886)-4-2284-0895 ext. 509; Fax: (886)-4-2286-2073; E-mail: hkooi@mail.nchu.edu.tw

Received February 10, 2012; Accepted April 20, 2012; Published April 28, 2012

Citation: Saito N, Higashiura K, Honma K, Kurosawa S, Ehata K, et al (2012) T-Cel Prolymphocytic Leukemia Accompanied by Plural M-Proteins with Myelodysplastic Syndrome in a Nonagenarian. J Clin Case Rep 2:131. doi:10.4172/21657920.1000131

Copyright: ( 2012 Saito N, et al. This is an open-access article distributed under the terms of the Creative Commons Attribution License, which permits unrestricted use, distribution, and reproduction in any medium, provided the original author and source are credited. 
observed (Figure 1b-1e). They were (i) the neutrophils, most of which have hypersegmented nuclei and with few cytoplasmic granules, (ii) the erythroblasts with nuclear division, the large platelets and the abnormal megakaryoblastic cells, and (iii) the reticulum cells which

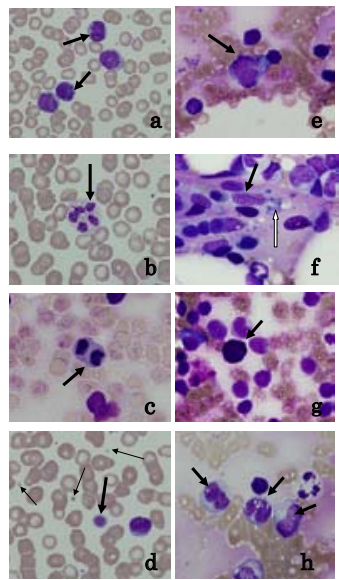

Figure 1: May-Grünwald-Giemsa stain

a. Small abnormal lymphoid cells (arrows) with an irregular nuclear outline in peripheral blood (PB) smear.

b. Neutrophil (arrow) with hypersegmented nucleus and few cytoplasmic granules in PB smear

c. Erythroblast in nuclear division (arrow) in bone marrow (BM) smear. d. Large platelet (arrow) in PB smear. Normal sized platelets (narrow arrow) are also seen.

e. Micromegakaryocyte-like cell (arrow) in BM smear.

f. Reticulum cell (arrow) with phagocytosed iron in its cytoplasm (white arrow) in BM smear.

g. Mast cell (arrow) seen in BM smear.

h. Medium-sized lymphocytic cells (arrows) with nuclear pockets in BM smear.

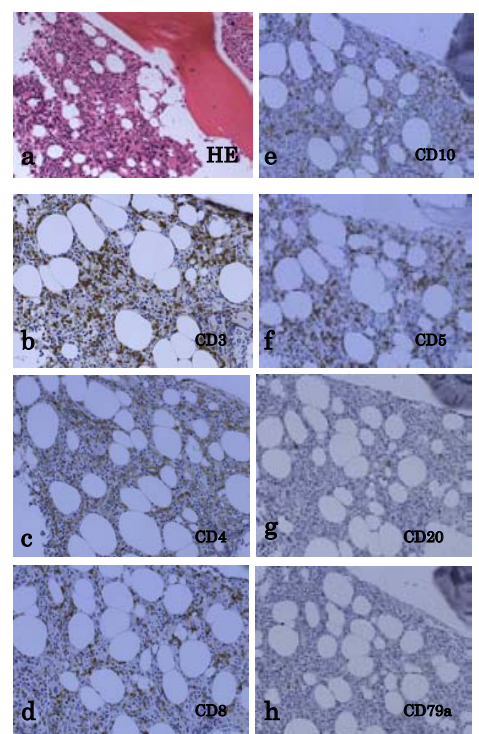

Figure 2: Hematoxylin-eosin (HE) and immuno-stainings in biopsied BM. a. Clusters of small lymphocytic cells as seen by HE stain. b. Strongly-stained cells positive cells for CD3.

c. Cells stained positive for CD4 stain are found scattered.

d. Strong-stained cells positive for CD8 stain are scattered.

e. Cells stained positive for CD10 are seen.

f. Cells stained positive for CD 5 are seen.

g. Cells are stained negative with anti-CD20 antibody.

h. Cells are stained negative with anti-CD79a antibody.

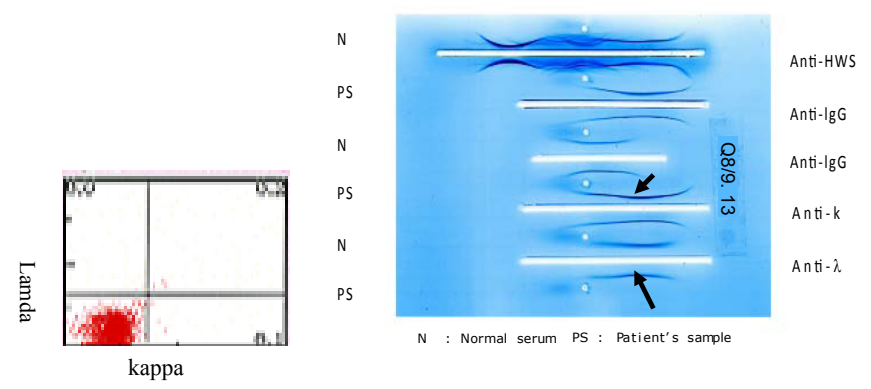

Figure 3: Immunoelectrophoresis

$\lg G_{K}$ is weakly detected. $\lg G \lambda$ is also faintly detected.

possessed iron in their cytoplasm. This is despite that the serum iron concentration, unsaturated iron binding capacity, total iron binding capacity and serum ferritin were found to be $29 \mu \mathrm{g} / \mathrm{dl}, 174 \mu \mathrm{g} / \mathrm{dl}$, $203 \mu \mathrm{g} / \mathrm{dl}$ and $122 \mathrm{ng} / \mathrm{ml}$, respectively (the normal range being 60 157, 190 269, 290 355, 13 215, respectively) (Figure 1f). Mast cells were also frequently observed (Figure1g). Large lymphocytic cells with nuclear pockets were also seen (Figure $1 \mathrm{~h}$ ). Chromosomal abnormality of 45 (X, 0 ) or loss of Y chromosome (in 4/20 analyzed cells) was also demonstrated. Serum Immunoglobulin (Ig) consisting of IgG at 2490 $\mathrm{mg} / \mathrm{dl}, \operatorname{IgA}$ at $439 \mathrm{mg} / \mathrm{dl}, \operatorname{IgM}$ at $154 \mathrm{mg} / \mathrm{dl}, \operatorname{IgE}$ at $753 \mathrm{IU} / \mathrm{ml}$ and $\operatorname{IgD}$ at $2.3 \mathrm{mg} / \mathrm{dl}$ (the normal range of the 5 classes of aforementioned serum Ig are 870 1700, 110 470, 23 250, 0 170, < 9, respectively) were observed. Serum IgG containing IgGkM-protein was slightly elevated. No Bence-Jones protein was detected in the urine. IgG $\lambda$ was faintly detected by immuno-electrophoresis (Figure 3). The C-reactive protein, anti-nuclear antibody titer and rheumatoid arthritis test were $0.35 \mathrm{mg} / \mathrm{dl}, \times 80$ and negative, respectively.

Since the measurements of his blood sedimentation test, D-dimer and Thrombin/Anti-Thrombin III (TAT) complex were $9 \mathrm{~mm} /$ hour, $3.2 \mu \mathrm{g} / \mathrm{ml}$ and $6.5 \mathrm{ng} / \mathrm{ml}$, respectively, coupled with low platelet count on admission, the patient was regarded as having a disseminated intravascular coagulation by leukemic cells, and needs to be administered nafamostat. While under a mild chemotherapy using a small amount of etoposide and prednisolone, he was supervened by acute pneumonia and died on the 42 nd day of his admission.

\section{Discussion}

The phenotype of the lymphocytic cells seen in our case was considered to be of the mature post-thymic stage T-cell and come under the category of the leukemic cells in T-cell prolymphocytic leukemia (T-PLL) because anti-HTLV-1 antibody could not be detected in the serum [7]. Although the leukemic cells of T-PLL generally show CD4 $(+)$ and CD8 (-) [8], those of our case were CD4 ( \pm ) and CD8 (+). Therefore, the cells seen in our case were considered to belong to a rare group in T-PLL. CD7, which is known to be positive in T-PLL [8], has also been reportedly detected on myeloid cells [9]. However, due to the relatively high cost of testing for CD7, we examined CD10 instead. The clinical course of T-PLL is progressively fast, and death usually occurs within one year [10]. In our case, the patient died at about 6 months after the practicing physician became aware of his lymphocytosis.

Several decades ago, T-PLL has been classified as one of the chronic T-cell leukemia, based on morphological, cytochemical and immunological evidences. However, the short survival time of this type of leukemia contradicts its characterization as being "chronic". Therefore, this type of leukemia is presently called T-PLL and thought 
to be a distinct pathophysiological entity because of recent evidences provided, such as cellular immunophenotyping $[11,12]$.

Soluble IL-2 receptor has been demonstrated to be able to activate B-cells or T-cells [13], especially the CD8 (+) T-cells [14]. The elevated IL-2 receptor seen in our case might have been the trigger for the proliferation of the leukemic cells belonging to CD8 (+), after his admission into our hospital.

Interestingly, this case also showed morphological abnormality in three cellular lineages coupled with chromosomal abnormality of 45

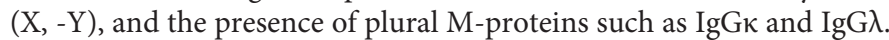
Previously, we have reported an MDS case with B-cell abnormality [15]. Since the leukemic cells in our present case were also positive for CD10, a marker which is also detected on immature B-cells, it is rational to implicate that certain kind of MDS cases might be related to B-cell disorder.

Since our patient in the present case was 96 years old, the morphological abnormalities seen in the three cellular lineages suggested that he might already have had the MDS disease long before the discovery of his T-PLL. Abnormality in 45 (X, 0) chromosome and the loss of Y chromosome, has been reportedly seen not only in MDS cases but also in normal elderly person [16,17]. Thus, our patient's chromosomal abnormality could not be determined as being due to MDS-related abnormality or to the high age-related one. However, he was suggested to have come down with MDS. A serum M-protein has been reportedly detected in elderly persons as well as in diseases other than B-cell malignancies [18-20]. Plural M-proteins observed in our elderly case with non-B cell leukemia would probably have come from his high age. The large lymphocytic cells with nuclear pockets seen in the bone marrow smears would not be capable of differentiating into leukemia-related cells associated with MDS, despite that abnormal cells with nuclear pockets had been observed in MDS-bone marrow cells in certain instances [15].

Several mast cells were found sporadically among the free cells from bone marrow in our case. His IgE was slightly elevated. Mast cells are well recognized as one of key effector cells in IgE-associated immune responses [21]. In addition, GATA-1 secreted from mast cells are known to influence erythropoiesis [22], megakaryopoiesis [23], and regulates CD8 (+) T-cell effector function [24]. Therefore, it is possible that those mast cells might be involved in the hemopoietic mechanism of his MDS and T-PLL. However, it is not clear whether the mast cells of this patient has any influence on the formation of the CD8 (+) leukemic cells or not.

It is generally regarded that MDS serve as a precursor phase leading to "myeloid" leukemia. What we had experienced here is truly a rare case that coincidentally showed T-PLL and MDS with plural M-proteins.

\section{References}

1. Ravandi F, O'Brien S (2005) Chronic lymphoid leukemias other than chronic lymphocytic leukemia: Diagnosis and treatment. Mayo Clin Proc 80: 16601674.

2. Foucar K (2007) Mature T-cell leukemias including T-prolymphocytic leukemia, adult T-cell leukemia/lymphoma, and Sézary syndrome. Am J Clin Pathol 127 496-510.

3. Kojima K, Kobayashi H, Imoto S, Nakagawa T, Matsui T, et al. (1998) 14q11 abnormality and trisomy $8 \mathrm{q}$ are not common in Japanese T-cell prolymphocytic leukemia. Int J Hematol 68: 291-296.

4. Greenberg $P$, Cox C, LeBeau MM, Fenaux P, Morel P, et al. (1997) International scoring system for evaluating prognosis in myelodysplastic syndromes. Blood 89: 2079-2088.

5. Aul C, Bowen DT, Yoshida Y (1998) Pathogenesis, etiology and epidemiology of myelodysplastic syndromes. Haematologica 83: 71-86.

6. Orazi A, Czader MB (2009) Myelodysplastic syndromes. Am J Clin Pathol 132 290-305.

7. Herling M, Khoury JD, Washington LT, Duvic M, Keating MJ, et al. (2004) A systematic approach to diagnosis of mature T-cell leukemias levels heterogeneity among WHO categories. Blood 104: 328-335.

8. Barito-Babapulle V, Pomfret M, Matutes E, Catovsky D (1987) Cytogenetic studies on prolymphocytic leukemia. II. T cell prolymphocytic leukemia. Blood 70: 926-931.

9. Ogata K, Nakamura K, Yokose N, Tamura H, Tachibana M, et al. (2002) Clinica significance of phenotypic features of blasts in patients with myelodysplastic syndrome. Blood 100: 3887-3896.

10. Matutes E, Brito-Babapulle V, Swansbury J, Ellis J, Morilla R, et al. (1991) Clinical and laboratory features of 78 cases of T-prolymphocytic leukemia. Blood 78: 3269-3274.

11. Volk JR, Kjeldsberg CR, Eyre HJ, Marty J (1983) T-cell prolymphocytic leukemia. Clinical and immunologic characterization. Cancer 52: 2049-2054.

12. Hallek M, Cheson BD, Catovsky D, Caligaris-Cappio F, Dighiero G, et al. (2008) Guidelines for the diagnosis and treatment of chronic lymphocytic leukemia: a report from the International Workshop on Chronic Lymphocytic Leukemia updating the National Cancer Institute-Working Group 1996 guidelines. Blood 111: $5446-5456$

13. Heaney ML, Golde DW (1996) Soluble cytokine receptors. Blood 87: 847-857.

14. Arima N, Matsushita K, Suruga Y, Ohtsubo H, Fujiwara H, et al. (1998) IL-2induced growth of $\mathrm{CD}^{+} \mathrm{T}$ cell prolymphocytic leukemia cells mediated by NFKB induction and IL-2 receptor $\alpha$ expression. Leuk Res 22: 265-273.

15. Saito N, Higashiura K, Ehata K, Kurosawa S, Honma K, et al. (2011) Myelodysplastic syndrome of del 20q with plasma cell dysplasia. J Clin Exp Hematop 51: 141-145.

16. United Kingdom Cancer Cytogenetics Group (UKCCG) (1992) Loss of the $Y$ chromosome from normal and neoplastic bone marrows. United Kingdom Cancer Cytogenetics Group (UKCCG). Genes Chromosomes Cancer 5: 83-88.

17. Herens C, Brasseur E, Jamar M, Vierset L, Schoenen I, et al. (1999) Loss of the $Y$ chromosome in bone marrow cells: results on 1907 consecutive cases of leukaemia and preleukaemia. Clin Lab Haematol 21: 17-20.

18. Crawford J, Eye MK, Cohen HJ (1987) Evaluation of monoclonal gammopathies in the "well" elderly. Am J Med 82: 39-45.

19. Danon F, Seligmann M (1973) Serum monoclonal immunoglobulins in childhood. Arch Dis Child 48: 207-211.

20. Passweg J, Thiel G, Bock HA (1996) Monoclonal gammopathy after intense induction immunosuppression in renal transplant patients. Nephrol Dial Transplant 11: 2461-2465.

21. Galli SJ, Nakae S, Tsai M (2005) Mast cells in the development of adaptive immune responses. Nat Immunol 6: 135-142.

22. Gutiérrez L, Tsukamoto S, Suzuki M Yamamoto-Mukai $H$, Yamamoto $M$, et al. (2008) Ablation of GATA 1 in adult mice results in aplastic crisis, revealing its essential role in steady-state and stress erythropoiesis. Blood 111: 4375-4385

23. Vyas P, Ault K, Jackson CW, Orkin SH, Shivdasani RA, et al. (1999) Consequences of GATA-1 deficiency in megakaryocytes and platelets. Blood 93: $2867-2875$

24. Stelekati E, Bahri R, D'Oriando O, Orinska Z, Mittrücker HW, et al. (2009) Mast cell-mediated antigen presentation regulates $\mathrm{CD} 8^{+} \mathrm{T}$ cell effector functions. Immunity 31: 665-676. 